\title{
Anti-Quorum Sensing Effects of Some Medicinal and Aromatic Plant Extracts on Xanthomonas axonopodis pv. Phaseoli ${ }^{\#}$
}

\author{
Tibebu Belete ${ }^{1, a}$, Kubilay Kurtulus Bastas ${ }^{2, b, *}$ \\ ${ }^{I}$ Rwanda Institute for Conservation Agriculture, Bugesera Campus, Bugesera, Rwanda \\ ${ }^{2}$ Department of Plant Protection, Faculty of Agriculture, Selçuk University, 42250Konya, Turkey
}

*Corresponding author

\begin{tabular}{|c|c|}
\hline R T I C L E I N F & T R A C T \\
\hline $\begin{array}{l}{ }^{\#} \text { This study was presented as an online } \\
\text { presentation at the } 2^{\text {nd }} \text { International } \\
\text { Journal of Agriculture - Food Science } \\
\text { and Technology (TURJAF 2021) } \\
\text { Gazimağusa/Cyprus } \\
\text { Research Article }\end{array}$ & $\begin{array}{l}\text { Xanthomonas axonopodis pv. phaseoli (Xap) is known as one of the most important seed-borne } \\
\text { destructive pathogens on beans worldwide. Nowadays, Xap is considered to acquire resistance to } \\
\text { antibiotics and synthetic bactericides which concerns the scientific world for its future management. } \\
\text { This has made the use of plant extracts, the best alternative in the control of plant disease pathogens } \\
\text { by inhibiting the quorum sensing (QS) mediated virulence factors. This research was designed to } \\
\text { investigate the antibacterial activities and the anti-QS effects of the } 14 \text { different aromatic and } \\
\text { medicinal plants against QS-mediated virulence factors of Xap. The results revealed that Syzgium } \\
\text { aromaticum showed the largest inhibition zone diameter and strongest antimicrobial (antibacterial) } \\
\text { effect among the } 14 \text { plant extracts followed by Thymus vulgaris and Coriandrum sativum. Similarly, } \\
\text { the lowest swarming, swimming, and twitching motility values were measured from the Syzgium } \\
\text { aromaticum application followed by Coriandrum sativum, Thymus vulgaris, Brassica nigra, } \\
\text { Lepidium sativum, and Ruta chalepenis. These results indicated that S. aromaticum, C. sativum, T. } \\
\text { vulgaris, B. nigra, L. sativum, and R. chalepenis will be a potential candidates as anti-quorum } \\
\text { sensing agents in preventing common bacterial disease of beans caused by Xap. Compounds derived } \\
\text { from aromatic and medicinal plants have demonstrated successful control of diseases in crops and } \\
\text { the use of these substances provides a valuable tool to the growers around the world for diseases } \\
\text { management in organic production. }\end{array}$ \\
\hline
\end{tabular}

tibebelete@gmail.com

\section{Introduction}

Common bean (Phaseolus vulgaris L.) is one of the main produced and consumed pulse crops worldwide (FAO, 2016) and its yield and seed quality are significantly decreased mainly due to common bacterial blight (CBB). According to Zaumeyer and Thomas (1957), CBB which is caused by Xap is a destructive disease of common bean worldwide. Since there is no satisfactory chemical control against Xap, biological control methods and the use of resistant varieties are important management strategies (Zapata, 1997).

Recently, the Quorum Sensing (QS) mechanism has become a new strategic target to combat pathogenic bacteria as a biological control mechanism, due to its main role in bacterial virulence and pro-survival effect on bacterial cells in biofilms (Yüzbaşığlu et al., 2018). The word QS is broadly defined as a cell-to-cell communication of bacteria through chemical language. The subsequent discovery of compounds that inhibit QS, named anti-QS agents could provide a new method of combating bacterial disease. The hazardous effect of the widely used synthetic chemicals to the environment and to human health makes the use of biologically active products (plant extracts and essential oils), an attractive alternative in the control of bacterial pathogens (Burt, 2004; Lo Cantore et al., 2009). QS systems have been shown to be inhibited by bioactive molecules produced by many aromatic and medicinal plants (Novick and Geisinger, 2008).

In the study of Adonizio et al., (2006) in South Florida, 50 medicinal plants were characterized for anti-QS activity using Chromobacterium violaceum and Agrobacterium tumefaciens as a bio-monitor strain. Of these plants, Chamaecyce hypericifolia, Conocarpus erectus, Bucida burceras, Callistemon viminalis, Tetrazygia bicolor, and Quercus virginiana showed QS inhibition activity. In another study, Mary and Banu (2015), the methanolic leaf extract obtained from Vitex trifolia showed anti quorum sensing activity in Pseudomonas aeruginosa. Al-Haidari et al. (2016) also reported that the extracts of some medicinal plants like Allium cepa, Laurus nobilis, Citrus sinensis, Coriandrum sativum, and Elettaria cardamomum, exhibited a potent quorum quenching effect. 
Crude extracts from Epilobium angustifolium, Tanacetum balsamita, Quercus robur and Quercus frainetto showed anti-QS activity and significantly reduced violacein production in C. violaceum (Yüzbaşığlu et al., 2018). AntiQS has also been demonstrated for plants originated from different regions including Europe (Tolmacheva et al., 2014), Korea (Damte et al., 2013), Iran (Mahmoudi et al., 2014), China (Koh and Tham, 2011) and India (Zahin et al., 2010). Similarly, in Ta et al. (2014) study, twelve of seventyone species collected from neotropical rainforests in Costa Rica were shown to possess significant anti-QS activities. Fruits such as blueberry, raspberry, cranberry, blackberry, and grape, and herbs including ginger, thyme, basil, oregano, kale and turmeric exhibited moderate inhibition of QS-controlled processes on $C$. violaceum bio-monitor strain and the swarming motility of $E$. coli and $P$. aeruginosa (Vattem et al., 2007). Of the 24 Indian medicinal plants screened, five of them demonstrated varying levels of violacein production in the reporter strains (Zahin et al., 2010). Likewise, Khan et al. (2009) reported that Syzygium aromaticum oil showed promising anti-QS activity on both wild and mutant strains followed by lavender, cinnamon, and peppermint oils. In South America, the Minthostachys mollis essential oil is a good candidate for the development of antiQS products with a potential application in the control of bacterial diseases mediated by QS (Pellegrini et al., 2014).
However, there was no study about the anti-QS effects of different plant extracts on QS-mediated virulence factors in the case of Xap. Management of CBB caused by Xap now a day is a challenge due to the limited efficacy of management strategies, as the pathogen acquires resistance to antibiotics and fixed copper bactericides and host resistance has not proven durable. Therefore, there is a need to develop an eco-friendly alternative and reducedrisk disease management approach.

In this study, we designed to evaluate the antibacterial activities and the anti-QS effects of the different aromatic and medicinal plants widely used in Ethiopia on QS mediated virulence factors swarming, swimming, and twitching motility of Xap.

\section{Materials and Methods}

\section{Plant Materials and Crude Extract Preparation}

Fourteen aromatic and medicinal plants (Table 1) were collected from local open markets of Addis Ababa town and purchased from different agricultural areas of Ethiopia. The collected plants and their parts were taxonomically identified and proved at Melkasa Agricultural Research Center and Addis Ababa University assisted by plant biologist and botanist professionals.

Table 1. Aromatic and medicinal plants used in the QS experiments against X. a. pv.phaseoli

\begin{tabular}{|c|c|c|c|c|}
\hline \multirow{2}{*}{ Common name } & \multirow{2}{*}{ Scientific Name } & \multicolumn{2}{|c|}{ Local name } & \multirow{2}{*}{ Plant parts used } \\
\hline & & Turkish & Amharic & \\
\hline Cinnamon & Cinnamon zeylanicum & Tarçin & Kerefa & Bark \\
\hline Clove & Syzgium aromaticum & Karanfil & Kurunfud & Flower Head \\
\hline Thyme & Thymus vulgaris & Kekik & Tosign & Leaf \\
\hline Mustard & Brassica nigra & Hardal & Snafich & Seed \\
\hline Black cumin & Nigella sativa L. & Çörek Otu & Tekur Azmud & Seed \\
\hline Garden cress & Lepidium sativum & Tere & Feto & Seed \\
\hline Ethiopian Mustard & Brassica carrinata & Hardal & Gomenzer & Seed \\
\hline Garlic & Allium sativum & Sarimsak & Nech shinkurt & Bulb \\
\hline Turmeric & Curcuma longa & Zerdeçal & Erd & Rhizome \\
\hline Coriander & Coriandrum sativum & Kişniş & Dinblal & Fruit \\
\hline Black pepper & Piper nigrum L. & Kara Biber & Kundu berbere & Fruit \\
\hline Garden Rue & Ruta chalepenis L. & Sedef Otu & Tena adam & Fruit \\
\hline Moringa & Moringa oleifera & Moringa & Shiferaw & Leaf \\
\hline Rosemary & Rosmarinus officinalis & Biberiye & Rozmary & Leaf shoot \\
\hline
\end{tabular}

Plant parts used for extraction were washed 2-3 times by running water and sterile distilled water, respectively. They were air-dried on a sterile blotter under shade at room temperature for 10 days (Soltani and Aliabadi, 2013). The plant parts of each aromatic and medicinal plant were ground by a grinding machine in the form of powder. Based on the procedures described by Kang et al. (2011), Soltani and Aliabadi (2013), Ibrahim and Abu-Salem (2014), Houshyar et al. (2014), Yavuz et al. (2017), and Ramena et al. (2018) with some modifications, 14 plant extracts were prepared as follows. Fifty grams of fine powder of each aromatic and medicinal plant part was soaked in $500 \mathrm{ml}$ of methanol $99 \%(\mathrm{v} / \mathrm{v})$ in a sterile container and incubated for seven days at normal temperature with manual shaking (Fig.1). Then the crude extract was filtered through Whatman filter paper and processed with Heidolph Rotary Evaporator for $40^{\circ} \mathrm{C}$ at 140rpm for the evaporation process. The extracts were stayed in the water bath for one day at about $40^{\circ} \mathrm{C}$ for complete removal of methanol. Finally, the semi-solid residues were stored aseptically in a sterilized bottle at $20^{\circ} \mathrm{C}$ until use.

\section{Evaluation of Antibacterial Activities of Crude Plant Extracts Against Xap}

To evaluate the antimicrobial activities of the medicinal and aromatic plant extracts against Xap isolate (145-X), the agar disc diffusion method was used as described by Chudasama and Thaker (2012), Houshyar et al. (2014), Bacha et al. (2016), and Yavuz et al. (2017) with some modifications. First a well-characterized by biochemical and molecular techniques and highly virulent isolate 145 $\mathrm{X}$ of Xap (92\%) was grown on yeast dextrose-calcium carbonate agar (YDC) medium for $48 \mathrm{hr}$ at $28^{\circ} \mathrm{C}$. Then 48 
hr old culture of Xap isolate was suspended in sterile deionized water, and adjusted using Bio-photometer (Eppendorph plus, OD650nm: 0.15) with an approximate concentration of $10^{8} \mathrm{CFU} \mathrm{mL} \mathrm{m}^{-1}$.

A100 $\mu$ l bacterial suspension was evenly spread over the prepared nutrient agar (NA) petri dishes with a $9 \mathrm{~cm}$ diameter to get uniform growth of Xap. After 15-20 min of bacterial inoculation, six-millimeter diameter sterilized standard paper discs were prepared and placed on the surface of inoculated culture plates with the help of sterile forceps. Stock solutions of plant extracts were prepared by dissolving $100 \mathrm{mg}$ of each plant extract in $1 \mathrm{ml}$ of 5\% (v/v) Dimethyl Sulfoxide (DMSO) and $15 \mu \mathrm{l}$ volume of each plant extract was pipetted (placed) onto the already prepared discs. Similarly, the same amount $(15 \mu \mathrm{l})$ of Gentamycin $(10 \mu \mathrm{g} / \mathrm{ml})$ and DMSO were poured onto paper discs and were used as positive and negative controls, respectively. The Petri plates were left under room temperature in a laminar cabin for about 20 min by sealing with sterile parafilm to allow the uniform diffusion of extracts into the gar plate and then the plates were incubated at $28^{\circ} \mathrm{C}$ for $48 \mathrm{hr}$. Finally, the diameters of the inhibition growth zone of each test extract generated around discs were measured in millimeters $(\mathrm{mm})$ to determine their antibacterial activity on Xap. The experiment was repeated twice with three replications and the results were summarized and expressed as mean $\pm \mathrm{SD}$ values.

\section{Minimum Inhibitory Concentration (MIC) Determination Assay}

Following the procedures of Bacha et al (2016) and Ramena et al. (2018) with modifications, the lowest or minimum concentration of the plant extract required to inhibit the growth of Xap was determined by a disc diffusion method. Alike the antimicrobial activity procedures above, standard sterilized paper discs (6 $\mathrm{mm}$ in diameter) were prepared for MIC determination. Consequently, the initial stock solution (concentration) of plant extract $(50 \mathrm{mg} / \mathrm{ml})$ was diluted in 1:2 serial dilutions. In other words, two-fold serial dilutions of each extract were prepared by dissolving 50, 25, 12.5, 6.25, $3.13,1.56$, and $0.78 \mathrm{mg}$ in $1 \mathrm{ml}$ of $5 \%$ (v/v) DMSO. Freshly prepared $48 \mathrm{~h}$ of Xap culture was suspended in sterile distilled water (SDW) with a final concentration of $10^{8} \mathrm{CFUmL}^{-1}$ and $100 \mu \mathrm{l}$ bacterial suspension was spread over the NA plate. After a few minutes of bacterial inoculation, seven sterilized paper discs were placed on the Petri dishes and tagging them as number one to seven, respectively with the above different extract concentrations (disc 1; $50 \mathrm{mg} / \mathrm{ml}$, disc 2; $25 \mathrm{mg} / \mathrm{ml}$, disc $3 ; 12.5 \mathrm{mg} / \mathrm{ml}$, etc.). All discs were loaded with the same amount of plat extracts $(15 \mu \mathrm{l})$ and the plates were incubated for $48 \mathrm{hr}$ at $28^{\circ} \mathrm{C}$. DMSO was used as a negative control. Finally, the zone of inhibition was observed and evaluated, and then the lowest concentration of plant extract $(\mathrm{mg} / \mathrm{ml})$ that prevented the visible growth of Xap was considered as the MIC. All samples were carried out in duplicates during MIC determination.

\section{The Anti-Quorum Sensing Potentials of Crude Plant Extracts on Xap}

Invitro evaluation of the anti-QS (swarming, swimming, and twitching motility inhibition) activities of the different plant extracts against Xap was conducted and the procedures were adapted from different researches (Hosseinzadeh et al., 2013; Zhang et al., 2014; Al-Haidari et al., 2016; Elmanama and Al-Refi, 2017; Singh et al., 2017a; Singh et al., 2017b).

\section{Swarming motility assay of Xap}

To conduct the swarming motility assays, the swarming medium and its plate were prepared using $0.8 \%(\mathrm{w} / \mathrm{v})$ of nutrient broth, $0.5 \%(\mathrm{w} / \mathrm{v})$ of glucose, and $0.5 \%(\mathrm{w} / \mathrm{v})$ of Bacto agar. Each ingredient was mixed together and adjusted the $\mathrm{pH}$ to 7.2 . The medium was sterilized at $121^{\circ} \mathrm{C}$ for 15 minutes and poured into the Petri plates when the medium was cooled to $50-45^{\circ} \mathrm{C}$. To evaluate the swarming motility inhibition potential of each plant extract, five $\mathrm{ml}$ of semi-solid agar/swarming medium was mixed with 200 $\mu l$ of each plant extract and poured into the prepared swarming plates as overly. The same amount $(200 \mu \mathrm{l})$ of DMSO (5\%) was poured instead of plant extracts as a negative control (Hosseinzadeh et al., 2013; Zhang et al., 2014; Al-Haidari et al., 2016; Elmanama and Al-Refi, 2017; Singh et al., 2017a; Singh et al., 2017b).

A pure colony of an overnight Xap isolate culture was selected and inoculated on the center of the swarming plate in the form of a point by using a sterile toothpick and plates were incubated at $28^{\circ} \mathrm{C}$ for $48 \mathrm{hr}$. Finally, hazy zone of motility, the migration distance (diameter) of Xap was measured in $\mathrm{mm}$ from the center (the diameter of circular bacterial growth from the point of inoculation was measured) and the percent inhibition of swarming motility of Xap in the presence of plant extracts as compared to control treatment was determined as follow.

$$
\% \mathrm{ISwaM}=\frac{\text { SwaMC }- \text { SwaME }}{\text { SwaMC }} \times 100
$$

Where,

$\%$ ISwaM= percent inhibition of swarming motility,

SwaMC $=$ swarming motility at control sample

SwaME $=$ swarming motility at extract sample

(Hosseinzadeh et al., 2013; Zhang et al., 2014; AlHaidari et al., 2016; Elmanama and Al-Refi, 2017; Singh et al., 2017a; Singh et al., 2017b).

Swimming and twitching motility assay

Both swimming and twitching motility tests were carried out with the same procedures of swarming test on swimming and twitching media. The swimming medium was prepared by using $1.0 \%$ tryptone, $0.5 \%$ yeast extract, and $0.3 \%$ agar, and twitching plates were prepared using $1 \mathrm{~g}$ tryptone, $0.5 \mathrm{~g}$ yeast extract, $0.5 \mathrm{~g} \mathrm{NaCl}$, and $1 \mathrm{~g}$ agar per $100 \mathrm{ml}$ of distilled water. Both motility media were adjusted to $7.2 \mathrm{pH}$ and sterilized at $121^{\circ} \mathrm{C}$ for 15 minutes and poured onto Petri plates. The swimming and twitching plates were allowed to dry at room temperature under a laminar cabin before being used. Alike swarming motility assay, to determine the swimming and twitching inhibition motility activities of plant extracts, five $\mathrm{ml}$ of semi-solid agar with $200 \mu \mathrm{l}$ of each plant extract was well mixed and poured onto the prepared swimming and twitching plants as an overlay. As usual, DMSO was used as a negative control. An overnight Xap culture was inoculated on the center of the swimming plates by taking its colony using a sterile toothpick. However, in the case of the twitching test, the colony of Xap was planted by immersing it in the bottom of the twitching plate at the center. The plates were incubated at $28^{\circ} \mathrm{C}$ for $48 \mathrm{hr}$ (Hosseinzadeh et al., 2013; Zhang et al., 2014; Al-Haidari et al., 2016; Elmanama and 
Al-Refi, 2017; Singh et al., 2017a; Singh et al., 2017b). At the end, the presence of a foggy zone of the motility (the diameter of the colony expansion) was measured and the average data are presented as means $\pm \mathrm{SD}$. All experiments were repeated twice and replicated three times by arranging in a completely randomized design (CRD). Reduction in swimming and twitching motility (percent inhibition of swimming and twitching motility) of Xap in the presence of plant extracts as compared to control treatment was estimated like the swarming test above.

\section{Statistical Analysis}

The data of each activity was analyzed for statistical significance using analysis of variance (ANOVA) of SAS software and mean separation was carried out using Duncan's Multiple Range Test (DMRT) at $0.99(\mathrm{P} \leq 0.01)$ level of confidence. For all cases, the average data are presented as means $\pm \mathrm{SD}$.

\section{Results}

Antibacterial Effects of Aromatic and Medicinal Plant Extract Against Xap and MIC Values of The Extracts

The antibacterial activity of aromatic and medicinal plant extracts against Xap showed that there was a highly significant difference among each extract for their inhibition zone diameter (Table 2 and Figure 1). All the extracts tested in the disc diffusion method showed an inhibition effect on the tested pathogen with different mean values (Figure 1). They showed various degrees of antibacterial effects against Xap ranging between 8-22.67 mm inhibition zone diameter. The crude extract from $S$. aromaticum, showed the strongest antibacterial effect and largest inhibition zone diameter $(22.67 \pm 1.16 \mathrm{~mm})$ among the tested plant extracts, which is almost near to the inhibition effect of the positive control gentamycin $(25 \pm 1.00 \mathrm{~mm})$. The second group of effective plant extracts included $T$. vulgaris $(15.33 \pm 0.58 \mathrm{~mm}), C$. sativum $(14.33 \pm 0.57 \mathrm{~mm}), N$. sativa $(14 \pm 1 \mathrm{~mm}), B$. nigra (13.33 $\pm 0.57 \mathrm{~mm})$, L. sativum $(13 \pm 1 \mathrm{~mm})$ and $R$. Chalepenis
(13 $\pm 1 \mathrm{~mm})$. C. longa, $P$. nigrum and A. sativum inhibited the growth of the bacterium by $12.00 \pm 0.0 \mathrm{~mm}, 11.33 \pm 0.58$ $\mathrm{mm}$, and $10.67 \pm 1.16 \mathrm{~mm}$, respectively. Next to $C$. zeylanicum and B. carrinata, extracts of $R$. officinalis and $M$. oleiferahade the least antibacterial activities on Xap with 8 $\mathrm{mm}$ diameter of zone of growth inhibition (Figure 1).

The tested plant extracts were further serially diluted to make different concentrations and determined their MICs. Consequently, the MICs values of different plant extracts were ranged between 1.56 to $50 \mathrm{mg} / \mathrm{ml}$. The lowest MIC value $(1.56 \mathrm{mg} / \mathrm{ml})$ was recorded from the extract $N$. sativa (Table 2). Generally, the estimated MICs values of the tested aromatic and medicinal plant extract obtained using the disc diffusion method for Xap bacteria were 1.56, 6.25, $12.5,25$, and $50 \mathrm{mg} / \mathrm{ml}$.

The Anti-QS Activity of Aromatic and Medicinal Plant Extracts On QS Mediated Factors of Xap

The effects of aromatic and medicinal plant extract on swarming, swimming and twitching motility ( $\mathrm{mm})$ and their percent inhibition (\%) of Xap isolate as compared to the control treatment (Table 3-5 and Fig. 2-7). The effect of plant extracts on both bacterial motility $(\mathrm{mm})$ and its percent reduction $(\%)$ as compared to control treatment were shown significantly $(\mathrm{P} \leq 0.01)$ different from the control treatment and each other. All plant extracts have significantly reduced the motility of Xap isolate in swarm plates. The mean of swarming, swimming, and twitching motility was ranged from 11.67-61.00 mm, 7.33-58.67 $\mathrm{mm}$, and 5.00-16.67 $\mathrm{mm}$, respectively. In all motility assays, the lowest motility values were measured from the S. aromaticum extract $(11.67 \mathrm{~mm}$ for swarming, $7.33 \mathrm{~mm}$ for swimming, and $5.00 \mathrm{~mm}$ for twitching motility)followed by $C$. sativum, T. vulgaris, B. nigra, $L$. sativum and $R$. chalepenis. However, all motility assessments (swarming, swimming, and twitching) were largely by far as compared to control plate [5\% DMSO (Only Xap)] (78.33 mm for swarming, $69.33 \mathrm{~mm}$ for swimming, and $21.00 \mathrm{~mm}$ for twitching) (Table 3-5).

Table 2. Mean of antibacterial activities (inhibition zone diameter in $\mathrm{mm}$ ) of tested aromatic and medicinal plant extracts and their MICs $\left(\mathrm{mgml}^{-1}\right)$ against Xap

\begin{tabular}{l|cc}
\hline \multicolumn{1}{c|}{ Plant extracts } & Inhibition zone diameter $(\mathrm{mm})$ & $\left.\mathrm{MIC}^{\mathrm{mgml}} \mathrm{m}^{-1}\right)$ \\
\hline Cinnamon (Cinnamon zeylanicum) & $9.67 \pm 0.58^{\mathrm{hij}}$ & 12.5 \\
Clove (Syzgium aromaticum) & $22.67 \pm 1.16^{\mathrm{b}}$ & 6.25 \\
Thyme (Thymus vulgaris) & $15.33 \pm 0.58^{\mathrm{c}}$ & 6.25 \\
Mustard (Brassica nigra) & $13.33 \pm 0.57^{\text {cdef }}$ & 25 \\
Black cumin (Nigella sativa L.) & $14.00 \pm 1.00^{\mathrm{cde}}$ & 1.56 \\
Garden cress (Lepidium sativum) & $13.00 \pm 1.00^{\mathrm{def}}$ & 25 \\
Ethiopian mustard (Brassica carrinata) & $9.00 \pm 0.00^{\mathrm{ij}}$ & 50 \\
Garlic (Allium sativum) & $10.67 \pm 1.16^{\mathrm{ghi}}$ & 50 \\
Turmeric (Curcuma longa) & $12.00 \pm 0.00^{\mathrm{efg}}$ & 6.25 \\
Coriander (Coriandrum sativum) & $14.33 \pm 0.57^{\mathrm{cd}}$ & 25 \\
Black pepper (Piper nigrum L.) & $11.33 \pm 0.58^{\mathrm{fgh}}$ & 25 \\
Garden Rue (Ruta chalepenis L.) & $13.00 \pm 1.00^{\mathrm{def}}$ & 12.5 \\
Moringa (Moringa oleifera) & $8.00 \pm 0.00^{\mathrm{j}}$ & $>50$ \\
Rosemary (Rosmarinus officinalis) & $8.00 \pm 0.00^{\mathrm{j}}$ & $>50$ \\
Gentamycin (positive control) & $25.00 \pm 1.00^{\mathrm{a}}$ & - \\
5\% DMSO (negative control) & $0.00 \pm 0.00^{\mathrm{k}}$ & - \\
\hline
\end{tabular}

Means that do not share a common letter within a column are significantly different from each other at $\mathrm{P} \leq 0.05$ according to DMRT. 
Table 3. Swarming motility (mm) and inhibition percentage of swarming motility of Xap in the presence of some aromatic and medicinal plant crude extracts

\begin{tabular}{l|cc}
\hline \multicolumn{1}{c|}{ Plant extracts } & $\begin{array}{c}\text { Diameter of swarming motility } \\
(\mathrm{mm})\end{array}$ & $\begin{array}{c}\text { Inhibition ofswarmingmotility } \\
\text { over control }(\%)\end{array}$ \\
\hline Cinnamon (Cinnamon zeylanicum) & $47.33 \pm 0.58 \mathrm{de}$ & $39.56 \pm 1.49 \mathrm{gh}$ \\
Clove (Syzgium aromaticum) & $11.67 \pm 0.58 \mathrm{~L}$ & $85.11 \pm 0.75 \mathrm{a}$ \\
Thyme (Thymus vulgaris) & $34.33 \pm 0.58 \mathrm{j}$ & $56.16 \pm 1.22 \mathrm{bc}$ \\
Mustard (Brassica nigra) & $35.33 \pm 0.58 \mathrm{ij}$ & $54.88 \pm 1.52 \mathrm{c}$ \\
Black cumin (Nigella sativa L.) & $40.33 \pm 1.53 \mathrm{~g}$ & $48.52 \pm 1.31 \mathrm{e}$ \\
Garden cress (Lepidium sativum) & $36.67 \pm 1.53 \mathrm{hi}$ & $53.20 \pm 1.17 \mathrm{~cd}$ \\
Ethiopian mustard (Brassica carrinata) & $56.67 \pm 0.58 \mathrm{c}$ & $27.63 \pm 2.11 \mathrm{i}$ \\
Garlic (Allium sativum) & $49.00 \pm 1.00 \mathrm{~d}$ & $37.45 \pm 0.24 \mathrm{~h}$ \\
Turmeric (Curcuma longa) & $61.00 \pm 1.00 \mathrm{~b}$ & $22.09 \pm 2.77 \mathrm{j}$ \\
Coriander (Coriandrum sativum) & $32.33 \pm 1.16 \mathrm{k}$ & $58.69 \pm 2.23 \mathrm{~b}$ \\
Black pepper (Piper nigrum L.) & $44.33 \pm 0.58 \mathrm{f}$ & $43.38 \pm 1.73 \mathrm{f}$ \\
Garden Rue (Ruta chalepenis L.) & $38.33 \pm 0.58 \mathrm{~h}$ & $51.04 \pm 1.59 \mathrm{de}$ \\
Moringa (Moringa oleifera) & $58.33 \pm 1.53 \mathrm{c}$ & $25.49 \pm 3.34 \mathrm{i}$ \\
Rosemary (Rosmarinus officinalis $)$ & $46.00 \pm 1.00 \mathrm{ef}$ & $41.27 \pm 1.40 \mathrm{fg}$ \\
Control (Only Xap) & $78.33 \pm 1.53 \mathrm{a}$ & -- \\
\hline \multicolumn{2}{l}{ Means that do not share a common letter within a column are significantly different from each other at P $\leq 0.05$ according to DMRT. }
\end{tabular}

Table 4. Swimming motility $(\mathrm{mm})$ and inhibition percentage of swimming motility of Xap in the presence of some aromatic and medicinal plant crude extracts

\begin{tabular}{l|cc}
\hline \multicolumn{1}{c|}{ Plant extracts } & Swimming motility(mm) & Inhibition of swimming(\%) \\
\hline Cinnamon (Cinnamon zeylanicum) & $41.67 \pm 0.58 \mathrm{de}$ & $39.90 \pm 0.88 \mathrm{fg}$ \\
Clove (Syzgium aromaticum) & $7.33 \pm 0.58 \mathrm{k}$ & $89.41 \pm 1.03 \mathrm{a}$ \\
Thyme (Thymus vulgaris) & $29.33 \pm 1.16 \mathrm{j}$ & $57.68 \pm 1.77 \mathrm{~b}$ \\
Mustard (Brassica nigra) & $31.67 \pm 1.53 \mathrm{i}$ & $54.33 \pm 1.93 \mathrm{c}$ \\
Black cumin (Nigella sativa L.) & $37.67 \pm 1.53 \mathrm{~g}$ & $45.63 \pm 3.19 \mathrm{e}$ \\
Garden cress (Lepidium sativum) & $34.00 \pm 1.00 \mathrm{~h}$ & $50.96 \pm 0.44 \mathrm{~d}$ \\
Ethiopian mustard (Brassica carrinata) & $45.33 \pm 0.58 \mathrm{c}$ & $34.59 \pm 1.78 \mathrm{~h}$ \\
Garlic (Allium sativum) & $43.00 \pm 1.00 \mathrm{~d}$ & $37.97 \pm 1.62 \mathrm{~g}$ \\
Turmeric (Curcuma longa) & $58.00 \pm 1.00 \mathrm{~b}$ & $16.34 \pm 0.50 \mathrm{i}$ \\
Coriander (Coriandrum sativum) & $28.33 \pm 1.16 \mathrm{j}$ & $59.10 \pm 2.51 \mathrm{~b}$ \\
Black pepper (Piper nigrum L.) & $39.67 \pm 0.58 \mathrm{f}$ & $42.76 \pm 2.05 \mathrm{ef}$ \\
Garden Rue (Ruta chalepenis L.) & $33.00 \pm 1.00 \mathrm{hi}$ & $52.37 \pm 2.47 \mathrm{~cd}$ \\
Moringa (Moringa oleifera) & $58.67 \pm 1.16 \mathrm{~b}$ & $15.38 \pm 0.62 \mathrm{i}$ \\
Rosemary (Rosmarinus officinalis) & $40.33 \pm 0.58 \mathrm{ef}$ & $41.81 \pm 1.63 \mathrm{f}$ \\
Control (Only Xap) & $69.33 \pm 1.53 \mathrm{a}$ & \\
\hline
\end{tabular}

Means that do not share a common letter within a column are significantly different from each other at $\mathrm{P} \leq 0.05$ according to DMRT.

Table 5. Twitching motility (mm) and inhibition percentage of twitching motility of Xap in the presence of some aromatic and medicinal plant crude extracts

\begin{tabular}{l|cc}
\hline \multicolumn{1}{c|}{ Plant extracts } & Twitching motility (mm) & Inhibition of twitching $(\%)$ \\
\hline Cinnamon (Cinnamon zeylanicum) & $16.33 \pm 0.58 \mathrm{bc}$ & $22.11 \pm 4.50 \mathrm{~h}$ \\
Clove (Syzgium aromaticum) & $5.00 \pm 0.00 \mathrm{~h}$ & $76.15 \pm 1.14 \mathrm{a}$ \\
Thyme (Thymus vulgaris) & $9.67 \pm 0.58 \mathrm{~g}$ & $53.98 \pm 1.40 \mathrm{~b}$ \\
Mustard (Brassica nigra) & $11.33 \pm 0.58 \mathrm{f}$ & $46.02 \pm 1.40 \mathrm{c}$ \\
Black cumin (Nigella sativa L.) & $14.00 \pm 0.00 \mathrm{e}$ & $33.23 \pm 3.18 \mathrm{ef}$ \\
Garden cress (Lepidium sativum) & $13.67 \pm 0.58 \mathrm{e}$ & $34.82 \pm 4.26 \mathrm{de}$ \\
Ethiopian mustard (Brassica carrinata) & $16.00 \pm 1.00 \mathrm{bc}$ & $23.62 \pm 7.11 \mathrm{gh}$ \\
Garlic (Allium sativum) & $16.33 \pm 0.58 \mathrm{bc}$ & $22.03 \pm 6.33 \mathrm{~h}$ \\
Turmeric (Curcuma longa) & $16.67 \pm 0.58 \mathrm{~b}$ & $20.59 \pm 1.91 \mathrm{~h}$ \\
Coriander (Coriandrum sativum) & $8.67 \pm 0.58 \mathrm{~g}$ & $58.66 \pm 3.47 \mathrm{~b}$ \\
Black pepper (Piper nigrum L.) & $14.67 \pm 0.58 \mathrm{de}$ & $30.13 \pm 1.63 \mathrm{efg}$ \\
Garden Rue (Ruta chalepenis L.) & $12.33 \pm 0.58 \mathrm{f}$ & $41.10 \pm 5.44 \mathrm{~cd}$ \\
Moringa (Moringa oleifera) & $16.33 \pm 0.58 \mathrm{bc}$ & $22.18 \pm 1.96 \mathrm{~h}$ \\
Rosemary (Rosmarinus officinalis) & $15.33 \pm 0.58 \mathrm{~cd}$ & $26.80 \pm 6.11 \mathrm{fgh}$ \\
Control (Only Xap) & $21.00 \pm 1.00 \mathrm{a}$ & \\
\hline
\end{tabular}

Means that do not share a common letter within a column are significantly different from each other at $\mathrm{P} \leq 0.05$ according to $\mathrm{DMRT}$. 


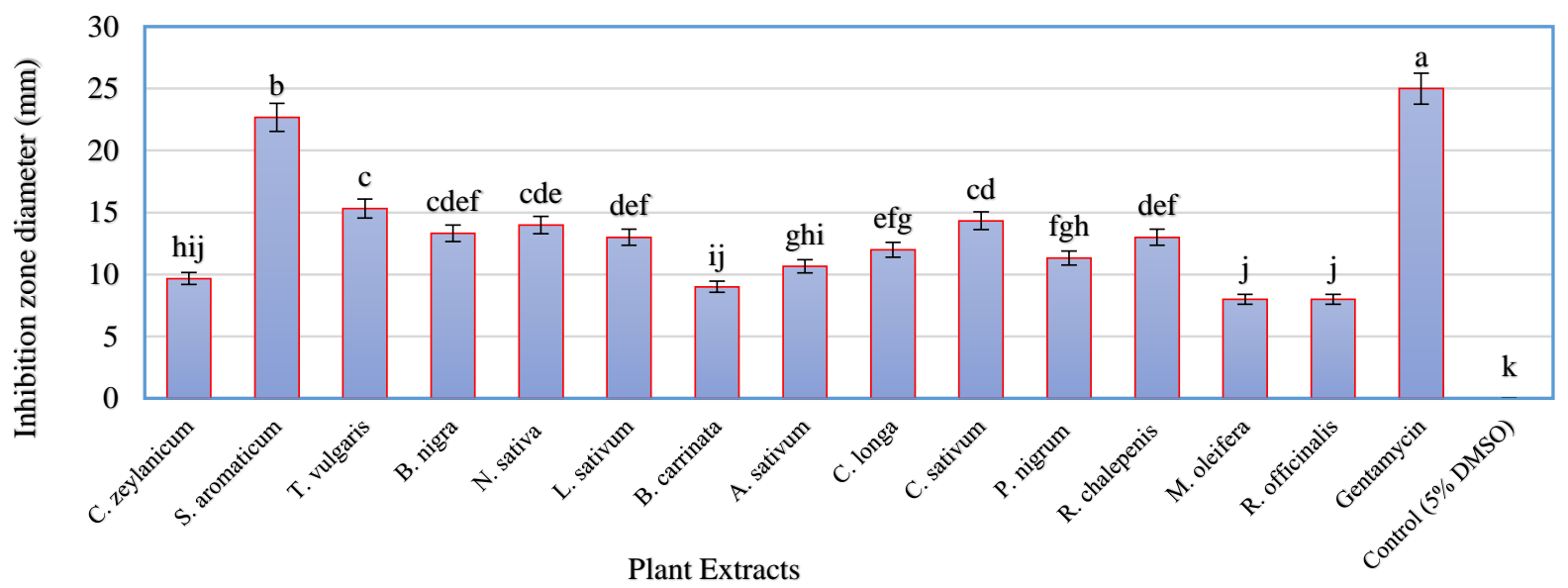

Figure 1. Antibacterial effects of 14 aromatic and medicinal plant extracts against Xap. Means that do not share a common letter in each bar are significantly different according to DMRT $(\mathrm{P} \leq 0.05)$ and vertical bars indicate standard errors of the mean.

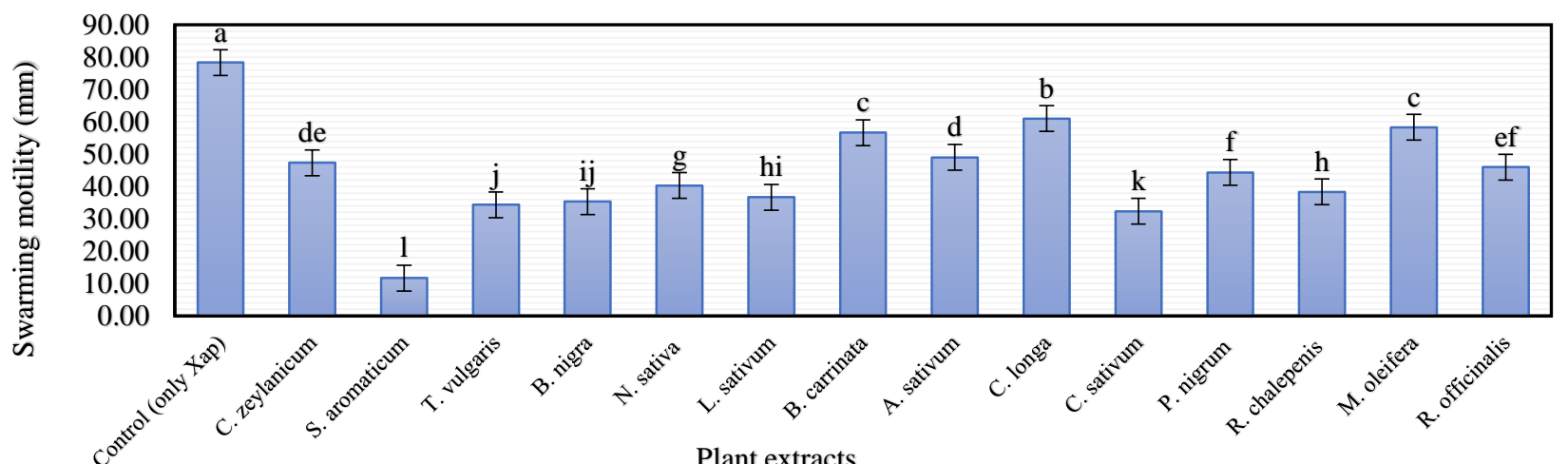

Figure 2. Swarming motility ( $\mathrm{mm}$ ) of Xap in the presence of aromatic and medicinal plant extracts. Means that do not share a common letter in each bar are significantly different according to DMRT $(\mathrm{P} \leq 0.05)$ and vertical bars indicate standard errors of the mean.

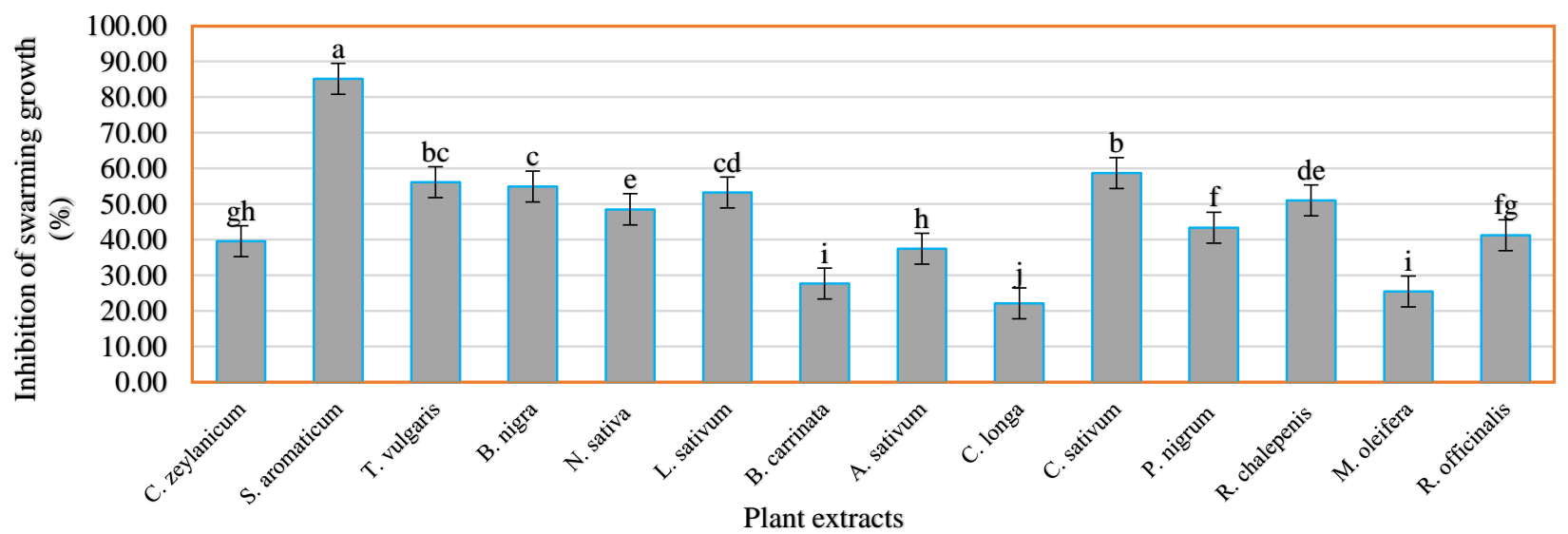

Figure 3. Percent inhibition of swarming motility of Xap in the presence of aromatic and medicinal plant extracts. Means that do not share a common letter in each bar are significantly different according to DMRT $(\mathrm{P} \leq 0.05)$ and vertical bars indicate standard errors of the mean.

The $S$. aromaticum extract reduced the swarming motility by $85 \%$, swimming motility by $89 \%$, and twitching motility by $76 \%$ over the control treatment (Table 3-5 and Fig. 2-7). In addition to $S$. aromaticum, a satisfactory result in inhibition of swarming, swimming, and twitching motility were also recorded in C. sativum, T. vulgaris, B. nigra, L. sativum, and $R$. chalepenis over control treatment. $C$. sativum, $T$. vulgaris, B. nigra, L. sativum, and $R$. chalepenis extracts reduced swarming in Xap by 58.69, 56.16, 54.88, 53.20, and 51.04\%, respectively. They also reduced the swimming motility by
$59.10,57.68,54.33,50.96$, and $52.37 \%$, respectively. These results indicated that crude extracts of $S$. aromaticum, $C$. sativum, $T$. vulgaris, B. nigra, $L$. sativum, and $R$. chalepenis had the greatest effect on swimming, swarming, and twitching motility of Xap. The least swimming, swarming, and twitching motility effect was observed by $B$. carrinata, $M$. oleifera, and $C$. longa. Their inhibition motility effect was less than by $40 \%$. Even though they had less effect as compared to other plant extracts, they were significantly different by far from the control treatment. 


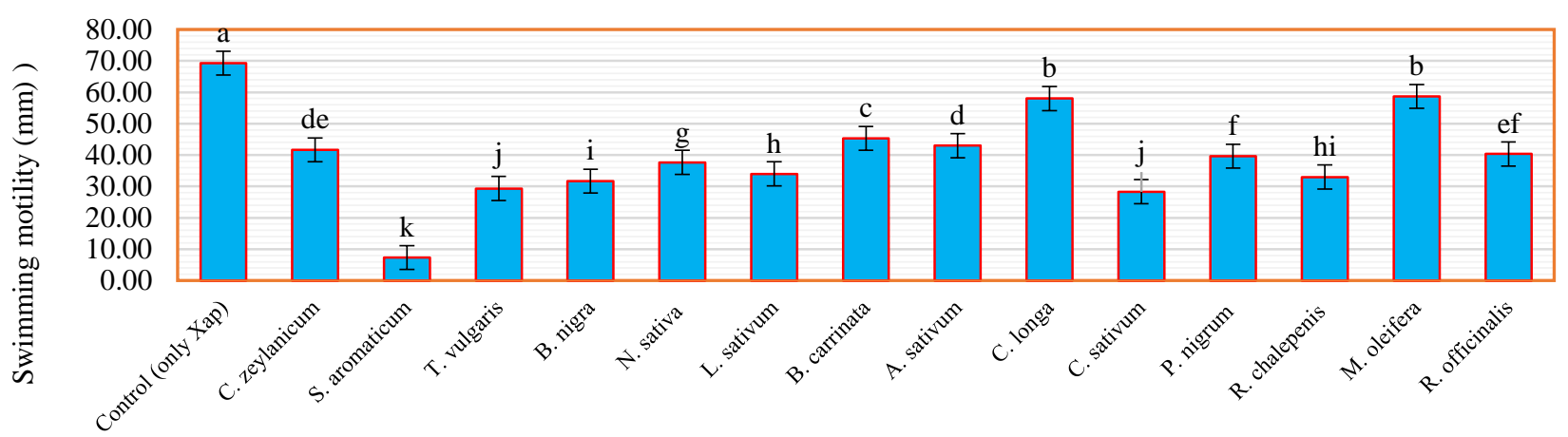

Figure 4. Swimming motility (mm) of Xap in the presence of some aromatic and medicinal plant crude extracts. Means that do not share a common letter in each bar are significantly different according to DMRT $(\mathrm{P} \leq 0.05)$ and vertical bars indicate standard errors of the mean.

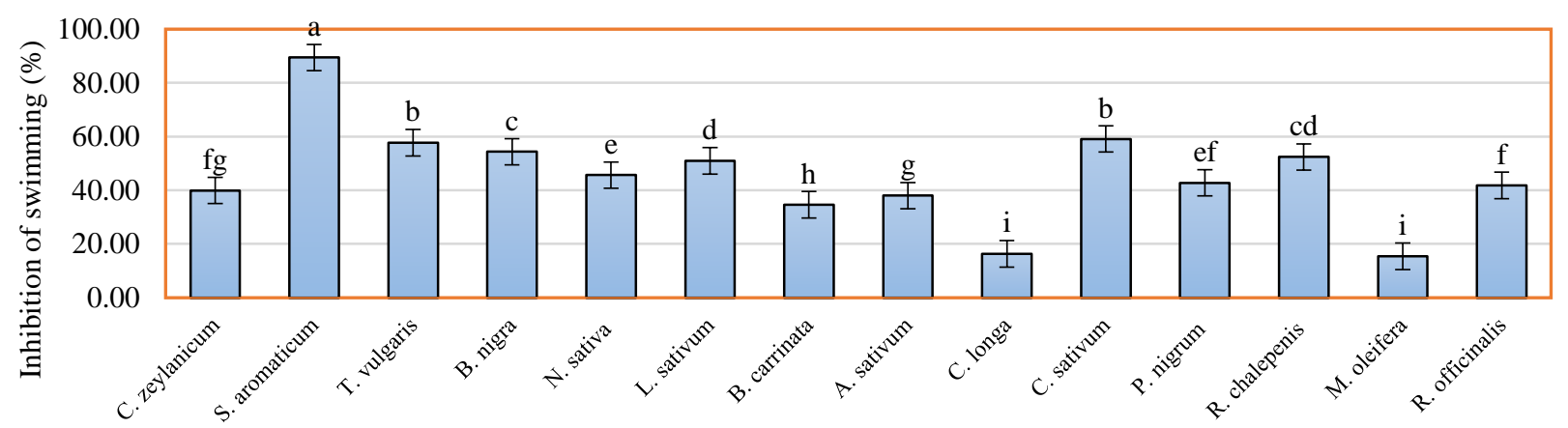

Figure 5. Percent inhibition of swimming motility of Xap in the presence of some aromatic and medicinal plant crude extracts. Means that do not share a common letter in each bar are significantly different according to DMRT $(\mathrm{P} \leq 0.05)$ and vertical bars indicatstandard errors of the mean.

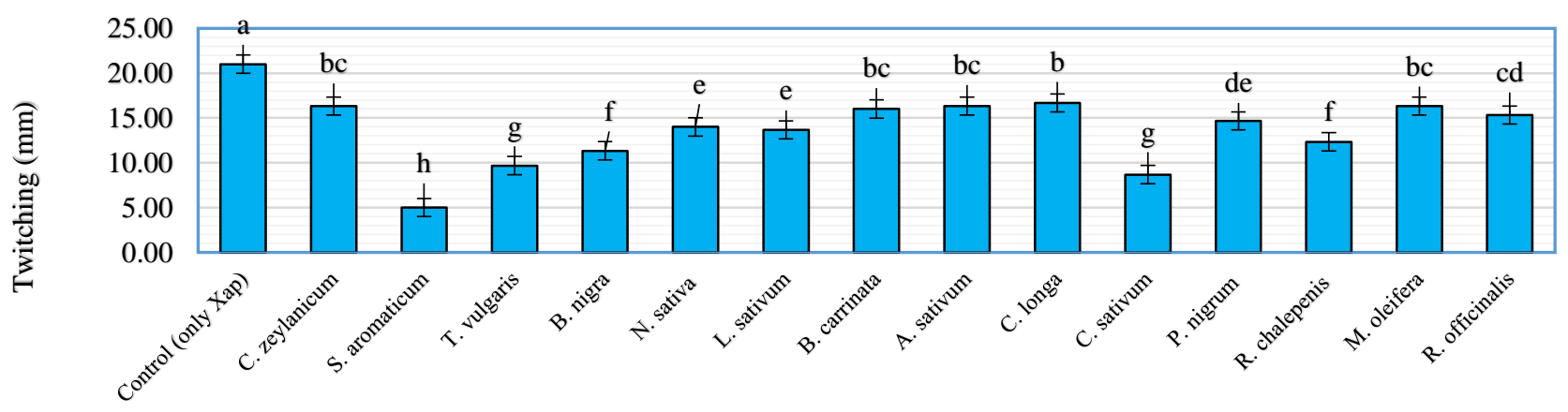

Figure 6. Twitching motility $(\mathrm{mm})$ of Xap in the presence of aromatic and medicinal plant extracts. Means that do not share a common letter in each bar are significantly different according to DMRT $(\mathrm{P} \leq 0.05)$ and vertical bars indicate standard errors of the mean.

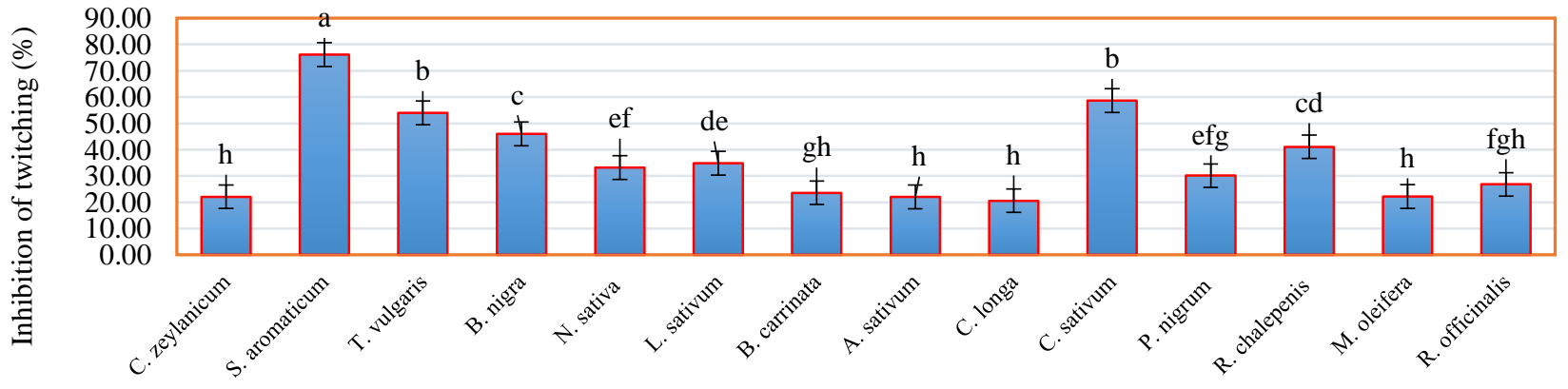

Figure 7. Percent inhibition of twitching motility of Xap in the presence of aromatic and medicinal plant extracts. Means that do not share a common letter in each bar are significantly different according to DMRT $(\mathrm{P} \leq 0.05)$ and vertical bars indicate standard errors of the mean. 


\section{Discussion}

Nowadays, Xap on bean plants exhibits resistance to many synthetic chemical compounds and antibiotics. Due to this problem, scientists are trying to develop new compounds to treat pathogenic bacteria as a biological control mechanism. That's why the use of plant extracts as an antibacterial effect is very important for eco-friendly management of plant diseases by reducing the usage of chemical compounds. In addition, developing eco-friendly compounds which are inhibiting and disturb the communication of bacterial pathogens (quorum sensing) is one of the most important approaches. Several strategies were set to inhibit the bacterial QS system. Disturbing and inhibiting QS signaling molecules and inhibiting bacterial diffusion (motility) are among the best strategies (Bouyahya et al., 2017).

The antibacterial bacterial activity of $S$. aromaticum extract in this study strongly agreed with the results of Benchouikh et al. (2016) who found that $S$. aromaticum had a strong antibacterial effect against the tested Xap isolates. Likewise, in Indian, Chudasama and Thaker (2012) were evaluated the antibacterial effect of many aromatic plant oil extracts against Xanthomonas campestris pv. citri indicated that $S$. aromaticum and $T$. vulgaris had strong zones of inhibition 24.33 and 23.66 mm, respectively. Hosseinzadeh et al. (2013) were reported T.vulgaris oil exhibited higher activity against $R$. solanacearum. Next $S$. aromaticum and $T$. vulgaris plant extracts, $C$. sativum was showed a potential antibacterial effect against Xap. A research result in Italy indicated C. sativum oil strongly inhibited the growth of $E$. coli and $B$. megaterium (Lo Cantore et al., 2004). In addition, the authors also reported $C$. sativuminhibited the growth of different strains of both gram-negative and gram-positive plant pathogenic bacteria (Pseudomonas, Erwinia, Xanthomonas, Agrobacterium, Clavibacter, Curtobacterium, and Rhodococcus). Similarly, Ibrahim and Abu-Salem (2014) reported, the methanol extracts of $S$. aromaticum showed high potential antibacterial activity against Bacillus cereus, Salmonella typhi, and Staphylococcus aureus. Aromatic and medicinal plants have different phenolic compounds that inhibit the activity of both gram-positive and negative bacteria. Sharma et al. (2014) and Benchouikh et al. (2016) reported that phenolic acids as a secondary plant metabolite such as eugenol, which is found in C. zeylanicum and S. aromaticum, have an antibacterial effect. Likewise, Soltani and Aliabadi (2013) reported the antibacterial activity of plant extracts is related to a number of flavonoids and phenolic compounds which are in pure form. Kasa and Woldeab (2015) were also evaluated the crude extracts of different plants against Xanthomonas campestris pv. musacearum in Ethiopia and identified a promising result for this pathogen.

Plant extracts have the ability to inhibit the expression of specific induced gene (s) during bacterial communication (El-Hamid, 2016). They are very important tools for the management and control of bacterial pathogenesis through modulation of bacterial virulence genes. In this study, the effect of crude plant extracts extracted from the different parts of aromatic and medicinal plants on swarming, swimming, and twitching motility of Xap was investigated. Among the tested plants $S$. aromaticum was the most effective in all assays (swarming, swimming, and twitching) over the control treatment. Small swimming, swarming, and twitching diameters were observed in $S$. aromaticum extract treatment which was in contrast with the control sets where the large diffused colony was observed on the swarm, swim, and twitch plates. Our results indicate that some aromatic and medicinal plant extracts were limit the migration of Xap bacteria on plates. Similar results investigated by You et al. (2007) and Koh and Tham (2011) the bud extract of S. aromaticum inhibit the QSmediated virulence factors (swimming, twitching, and swarming) of Pseudomonas aeruginosa. Likewise, among the 21 essential oils screened by Khan et al. (2009), a significant QS inhibition effect was observed in $S$. aromaticum oil against $C$. violaceum strains. These authors reported a $78 \%$ reduction in swarming motility by $S$. aromaticumon $P$. aeruginosa. In addition, a study by Ganesh and Rai (2015) indicated essential oils of $S$. aromaticum, $R$. officinalis, $C$. verum, and $C$. longa has shown anti-QS activity against $P$. aeruginosa. They also reported the essential oils of $C$. verum and $S$. aromaticum decreased the swarming motility of the tested bacterial pathogens. The QS inhibition effect of C. zeylanicum was relatively less intense against the $C$. violaceum strains (Khan et al., 2009). According to Pfeilmeier et al. (2016), bacterial pathogen must migrate from the epiphytic surface to the inside tissue of the infecting plant using motility and chemotaxis machinery to get successful infection development. C. sativum and $T$. vulgaris had also a strong effect on the motility assay of Xap isolate. This indicates that both aromatic and medicinal plant extracts constitute a promising ingredient for the management and control of bacterial disease through the modulation of bacterial virulence factors (El-Hamid, 2016). A research result by Singh et al. (2017a) demonstrated T. vulgarisoil had a considerable reduction effect in swarming and swimming motility (1.24 and 1.19 fold, respectively) as compared to the control treatment. According to Al-Haidari et al. (2016), the anti-quorum sensing effect of alcohol extracts of medicinal plants was evaluated against $C$. violaceum bacteriaand the result revealed that $C$. sativum and $A$. cepa had a significant effect. They also indicated these plant extracts manifested a distinct effect on motility (swarming and twitching) of P. aeruginosa.

The production of surfactant molecules which mainly play an important role in facilitating the swarming motility of bacteria are triggered by acyl-homoserine lactones (AHLs) (Eberl et al., 1996). Any natural plant compound that inhibits the swarming, swimming, and twitching motility is more likely to hinder the production of quorum sensing molecules.

\section{Conclusion}

The results from our antibacterial study indicate that the use of different aromatic and medicinal plant extracts especially $S$. aromaticum, T. vulgaris, C. sativum, $N$. sativa, B. nigra, L. sativum and $R$. chalepenis were showed a potential antibacterial effect on Xap isolate under in-vitro 
conditions and may use as a natural bactericide (biological control) for the management of bean bacterial disease caused by Xap under field conditions and for seed treatment in organic agriculture.

Generally, in our study, the plant extracts from $S$. aromaticum, C. sativum, T. vulgaris, B. nigra, L. sativum, and $R$. chalepenis were more effective and superior to the remaining tested plant extracts indicated antibacterial activities and swimming, swarming, and twitching motility inhibition and recommended that the importance of aromatic and medicinal plant extracts as a rich source of compounds able to inhibit QS mediated virulence factors. They could manage $\mathrm{CBB}$ disease development and hinder its dissemination. Therefore, further investigation on the nature of these anti-QS plant extract compounds on this particular bacterium and their mode of action is still required.

\section{Funding}

This project was supported by the Scientific Research Project Coordination Unit (No.18201104) of Selcuk University, Turkey for providing the Ph.D. scholarship for this study. The funder had no role in study design, data collection, and analysis, decision to publish, or preparation of the manuscript.

\section{Conflicts of interest}

The authors declare that they have no competing interests.

\section{References}

Adonizio AL, Downum K, Bennett BC, Mathee K. 2006. Antiquorum sensing activity of medicinal plants in southern Florida.J Ethnopharmacol105, (3):427-435.

Al-Haidari RA, Shaaban ML, Ibrahim SRM, Mohamed GA. 2016. Anti-quorum sensing activity of some medicinal plants. Afr J Tradit Complement Altern Med.13(5):67-71.

Bacha K, Tariku Y, GebreyesusF, Zerihun S, Mohammed A, Weiland-Bräuer N, Schmitz RA,Mulat M. 2016. Antimicrobial and anti-quorum sensing activities of selected medicinal plants of Ethiopia: Implication for development of potent antimicrobial agents, BMC Microbiol, 16(1): 139.

Benchouikh A, Allam T, Kribii A, Khadija O. 2016. Morphological and biochemical characterization of Xanthomonas axonopodis pv. phaseoli and antimicrobial activity in vitro of the essential oil of Cinnamomum zeylanicum, Nigella sativa and Syzygium aromaticum L. IJIRSET,5(11):18819-18827.

Bouyahya A, Dakka N, Et-Touys A, Abrini J, Bakri Y. 2017. Medicinal plant products targeting quorum sensing for combating bacterial infections. Asian Pac J Trop Med.10(8):729-743

Burt S. 2004. Essential oils: their antibacterial properties and potential applications in foods. Int J Food Microbiol, 94 (3):223-253.

Chudasama KS, Thaker VS. 2012. Screening of potential antimicrobial compounds against Xanthomonas campestris from 100 essential oils of aromatic plants used in India: an ecofriendly approach. Arch Phytopathol Pflanzenschutz, 45(7):83-795.

Damte D, Gebru E, Lee SJ, Suh JW. 2013. Evaluation of antiquorum sensing activity of 97 indigenous plant extracts from Korea through bioreporter bacterial strains Chromobacterium violaceum and Pseudomonas aeruginosa. J. Microb. Biochem. Technol, 5(2):42-46.
Eberl L, Winson MK, Sternberg C, Stewart GS, Christiansen G, Chhabra SR, Givskov M. 1996. Involvement of N-acyl-1homoserine lactone autoinducers in controlling the multicellular behaviour of Serratia liquefaciens. Mol Microbiol, 20(1):27-136.

El-Hamid MIA. 2016. A new promising target for plant extracts: Inhibition of bacterial quorum sensing.J Mol Microb Biotech, $1: 1$.

Elmanama AA, Al-Reefi MR. 2017. Antimicrobial, anti-biofilm, anti-quorum sensing, antifungal and synergistic effects of some medicinal plants extracts. IUG Journal of Studies, 25 (2):198-20.

FAO, 2016. Food and Agriculture Organization of the United Nations Statistics. http://www.fao.org/faostat/en/\#rankings/countries_by_com modity (access date: Jan 2018).

Ganesh PS, Rai VR. 2015. Evaluation of anti-bacterial and antiquorum sensing potential of essential oils extracted by supercritical CO2 method against Pseudomonas aeruginosa. J. Essent Oil-Bear Plants, 18(2):264-275.

Hosseinzadeh S, Shams-Bakhsh M, Hosseinzadeh E. 2013. Effects of sub-bactericidal concentration of plant essential oils on pathogenicity factors of Ralstonia solanacearum. Arch Phytopathol Pflanzenschutz, 46(6):643-655.

Houshyar F, Jamshidi S, Sohrabi M. 2014. Antimicrobial in vitro and in vivo potential of five lichen species onFusarium Equiseti and Pectobacterium carotovora pv. carotovora causal agents of potato rots. IJABBR, 2(4):412-417.

Ibrahim HM, Abu-Salem FM, 2014. Antibacterial activity of some medicinal plant extracts. World Acad Sci Eng Technol, 8(10):1168- 1173.

Kang CG, Hah DS, Kim CH, Kim YH, Kim E, Kim JS. 2011. Evaluation of antimicrobial activity of the methanol extracts from 8 traditional medicinal plants. Toxicol Res, 27(1):31-36.

Kasa D, Woldeab G. 2015. Evaluation of different botanical plant extracts and other materialagainst enset bacterial wilt (Xanthomonas campestris pv.musacearum) disease in Oromia Regional State, Ethiopia.ARPN J Eng Appl Sci, 5(2):68-73.

Khan MSA, Zahin M, Hasan S, Husain FM, Ahmad I. 2009. Inhibition of quorum sensing regulated bacterial functions by plant essential oils with special reference to clove oil.Lett Appl Microbiol, 49:354-360.

Koh KH,Tham FY. 2011. Screening of traditional Chinese medicinal plants for quorum-sensing inhibitors activity. J Microbiol Immunol Infect, 44(2):144-148.

Lo Cantore P, Iacobellis NS, De Marco A, CapassoF, Senatore F. 2004. Antibacterial activity of Coriandrum sativum L. and Foeniculum vulgare Miller var. vulgare (Miller) essential oils. J Agric Food Chem, 52:7862-7866.

Lo Cantore P, Shanmugaiah V, Iacobellis NS. 2009. Antibacterial activity of essential oil components and their potential use in seed disinfection.J Agric Food Chem,57:9454-9461.

Mahmoudi E, Tarzaban S, Khodaygan P. 2014. Dual behaviour of plants against bacterial quorum sensing: Inhibition or excitation.Int J Plant Pathol 96 (2): 295-301.

Mary RNI, Banu N. 2015. Screening of anti-biofilm and antiquorum sensing potential of Vitex Trifolia in Pseudomonas Aeruginosa.Int J Pharm, 7(8):243-245.

Novick RP, Geisinger E. 2008. Quorum sensing in staphylococci.Annu Rev Genet, 42:541-564.

Pellegrini MC, Alvarez MV, Ponce AG, Cugnata NM, De Piano FG, Fuselli SR. 2014. Anti-quorum sensing and antimicrobial activity of aromatic species from South America.J Essent Oil Res, 26 (6):458-465.

Pfeilmeier S, Caly DL, Malone JG. 2016. Bacterial pathogenesis of plants: future challenges from a microbial perspective: challenges in bacterial molecular plant pathology. Mol Plant Pathol, 17(8):1298-1313. 
Ramena G, Ramena Y, Challa N. 2018. Identification and determination of minimum inhibitory concentrations of plant extracts having antimicrobial activity as potential alternative therapeutics to treat Aeromonas hydrophila infections. Microb Pathog, 2(1):1-9.

Sharma S, Singh S, Bond J, Singh A, Rustagi A. 2014. Evaluation of antibacterial properties of essential oils from Clove and Eucalyptus.Asian J Pharm Clin Res, 7(5):291-294.

Singh A, Gupta R, Tandon S, Pandey R. 2017a. Thyme oil reduces biofilm formation and impairs virulence of Xanthomonas oryzae. Front Microbiol, 8:1074.

Singh A, Gupta R Tandon S, Pandey R. 2017b. Antivirulence activity of essential oils against Xanthomonas oryzae pv. oryzae causing bacterial blight of Oryza sativa.Int $\mathrm{J}$ agric Environ Biotechnol, 10(4): 499-505.

Soltani J, Aliabadi AA. 2013. Antibacterial effects of several plant extracts and essential oils on Xanthomonas arboricola pv. juglandis in vitro.J Essent Oil-Bear Plants, 16 (4): 461468.

Ta CA, Freundorfer M, Mah TF, Otárola-Rojas M, Garcia M, Sanchez-Vindas P, Poveda L, Maschek JA, Baker BJ, Adonizio AL, Downum K, Durst T,Arnason JT. 2014. Inhibition of bacterial quorum sensing and biofilm formation by extracts of neotropical rainforest plants.Planta Med, 80(4):343-350.

Tolmacheva AA, Rogozhin EA, DeryabinDG. 2014. Antibacterial and quorum sensing regulatory activities of some traditional Eastern-European medicinal plants.Acta Pharmaceut, 64(2):173-186.
Vattem DA, Mihalik K, Crixell SH Mcleand RJ. 2007. Dietary phytochemicals as quorum sensing inhibitors.Fitoterapia, 78(4):302-310

Yavuz C, Kılıç DD, Ayar A, Yıldırım T. 2017. Antibacterial effects of methanol extracts of some plant species belonging to Lamiaceae family.International Journal of secondary Metabolite, 4(3):429-433.

You J, Xue X, Cao L, Lu X, Wang J, Zhang L, Zhou S. 2007. Inhibition of Vibrio biofilm formation by a marine actinomycete strain A66. Appl Microbiol Biotechnol, 76(5):1137-1144.

Yüzbaşıŏglu EÇ, Bona M, Şerbetçi T, Gürel F. 2018. Evaluation of quorum sensing modulation by plant extracts originating from Turkey.Plant Biosystems, 152(3):376-385.

Zahin M, Hasan S, Aqil F, Khan MS, Husain FM,Ahmad I. 2010. Screening of certain medicinal plants from India for their antiquorum sensing activityIndian J Exp Biol,48(12):1219-1224.

Zaumeyer WJ, Thomas HR. 1957. A monographic study of bean diseases and methods for their control, United States Depertment of Agriculture Technical Bulletin, 868:255.

Zapata M. 1997. Identificación de Razas de Xanthomonas campestris pv. phaseoli en Hojas de Phaseolus vulgaris. MESOAMERICANA, 8(1): 4452.

Zhang J, Rui X, Wang L, GuanY, Sun X, Dong M. 2014. Polyphenolic extract from Rosa rugosa tea inhibits bacterial quorumsensing and biofilm formation. Food Control, 42:125131. 